\title{
Soil erosion vulnerability in the southern part of the Meia Ponte watershed, Goias, Brazil
}

\author{
Vulnerabilidad erosiva del suelo en la parte sur \\ de la cuenca Media Ponte, Goias, Brasil \\ Breno Amaro da Silva ${ }^{1}$, Pedro Rogerio Giongo ${ }^{1 *}$, \\ Patrick Tomaz de Aquino Martins ${ }^{1}$, Thaís Alves Barbosa ${ }^{2}$, Victor Hugo Moraes ${ }^{2}$, \\ Thomas Jefferson Cavalcante ${ }^{2}$, Angelina Maria Marcomini Giongo ${ }^{1}$
}

\begin{abstract}
Soil erosion is a serious environmental problem that can cause numerous types of damage to society and the environment, and thus require preventive measures. The objective of this study was to evaluate soil erosion vulnerability in the southern region of the Meia Ponte watershed, Goias, Brazil, considering two situations: natural and anthropic cover conditions. For the analysis, we used remote sensing data represented by several parameters: lithology, soil class, slope, rain intensity, vegetation index, vicinity of roads, and land use and occupation. For each variable, we established a scale of weights according to erosive susceptibility for natural and anthropogenic environments. Multicriteria analysis, which allows the combination of qualitative and quantitative information in the analysis of erosive susceptibility, was used through the relationship between soil use and land occupation. In the southern part of the Meia Ponte River watershed, the anthropic factor showed greater influence. The factors that increase erosive susceptibility were soil use and occupation, low vegetation index, and high slope. The southern part of the Meia Ponte watershed presents medium natural erosive susceptibility in most of the study area.
\end{abstract}

Key words: remote sensing, GIS, cerrado, anthropization.

\section{RESUMEN}

La erosión de los suelos es un grave problema ambiental que puede ocasionar numerosos daños a la sociedad y al medio ambiente, siendo necesario la adopción de medidas preventivas. Este estudio tuvo por objetivo evaluar la vulnerabilidad erosiva de los suelos en la región sur de la cuenca Meia Ponte, Goiás, considerando dos situaciones: condiciones de cobertura natural y antrópica. Para la realización de los análisis, se utilizaron datos de sensoriamiento remoto representados por diversos parámetros: litología, clase de suelo, declividad, intensidad de lluvia, índice de vegetación, cercanías de vías y uso y ocupación del suelo. Se establecieron para cada variable, una escala de pesos de acuerdo con susceptibilidad erosiva para el medio natural y otra antrópica. Se utilizó el análisis multicriterio, por medio de la relación entre las actividades de uso y ocupación del suelo, la cual permite combinar informaciones cualitativas y cuantitativas en análisis en cuanto a la susceptibilidad erosiva. En la parte sur de la cuenca del Río Meia Ponte, el factor antrópico obtuvo mayor influencia. Los factores que aumentaron susceptibilidad erosiva fueron el uso y ocupación del suelo, bajo índice de vegetación y la alta declividad. La parte sur de la cuenca Media Ponte, presenta susceptibilidad erosiva natural media en la mayor parte del área de estudio.

Palavras Clave: detección remota, SIG, cerrado, antropización.

\section{Introduction}

The central-west region of Brazil has been undergoing an intense process of land occupation resulting from urbanization and mainly agricultural activities (Lepsch, 2010). The change in land use from native vegetation to areas occupied by agriculture, pasture, and urban areas (Moraes et al., 2019) has promoted changes in the pattern of biophysical variables, causing silting of reservoirs and water courses, loss of fertile soils (Assis et al., 2017), and finally contributing to soil erosion processes.

Soil erosion is a serious global environmental problem that can cause great damage to society

\footnotetext{
1 Universidade Estadual de Goias, Santa Helena de Goias, Goias- Brasil.

2 Instituto Federal Goiano, Rio Verde, Gois, Brasil

* Corresponding author: pedro.giongo@ueg.br
} 
and the environment. The erosion process is a phenomenon that may occur through millions of years, causing impacts and transformations in the topography of the surface soil and alteration in sedimentary rocks (Ismael et al, 2013). Preventive measures are necessary to ensure that there are no increases in the areas affected by erosion, which could possibly increase the risk of food shortages for the population depending on agricultural production (Zanata, 2012).

Geomorphology can make important contributions to the study and planning of urban and rural areas, because development has occurred at an accelerated pace and often does not obey the natural characteristics and limitations of the environment (Christofoletti, 2011). Considering the importance of knowing and seeking measures for erosion control, geomorphological analysis and geoprocessing techniques have become relevant in these studies. With the use of thematic mapping, it is possible to identify erosive features and areas prone to erosion and also to facilitate analysis of the natural or anthropogenic environmental variables that incur erosion. In conjunction with this type of analysis, it is important to verify or elaborate measures of control (Nascimento, 2005; Silva and Machado, 2014).

Geographic information systems (GIS), together with geoprocessing techniques, are an important technique for environmental studies with constant integration and updating of spatial and alphanumeric data. They also allow analysis of phenomena at different scales and simulation of situations and environmental planning for decision making (Pina, 1998; Zanata, 2012). In view of the above, this study aimed to evaluate soil erosion vulnerability in the southern region of the Meia Ponte watershed, Goias, Brazil, considering two situations: natural and anthropic cover conditions.

\section{Material and Methods}

This study was carried out in the southern part of the Meia Ponte River watershed, partially covering 10 municipalities in the state of Goias (Figure 1). The climate of the region is classified as type Aw (tropical subhumid) according to Koppen-Geiger classification. It has a rainy season in the winter

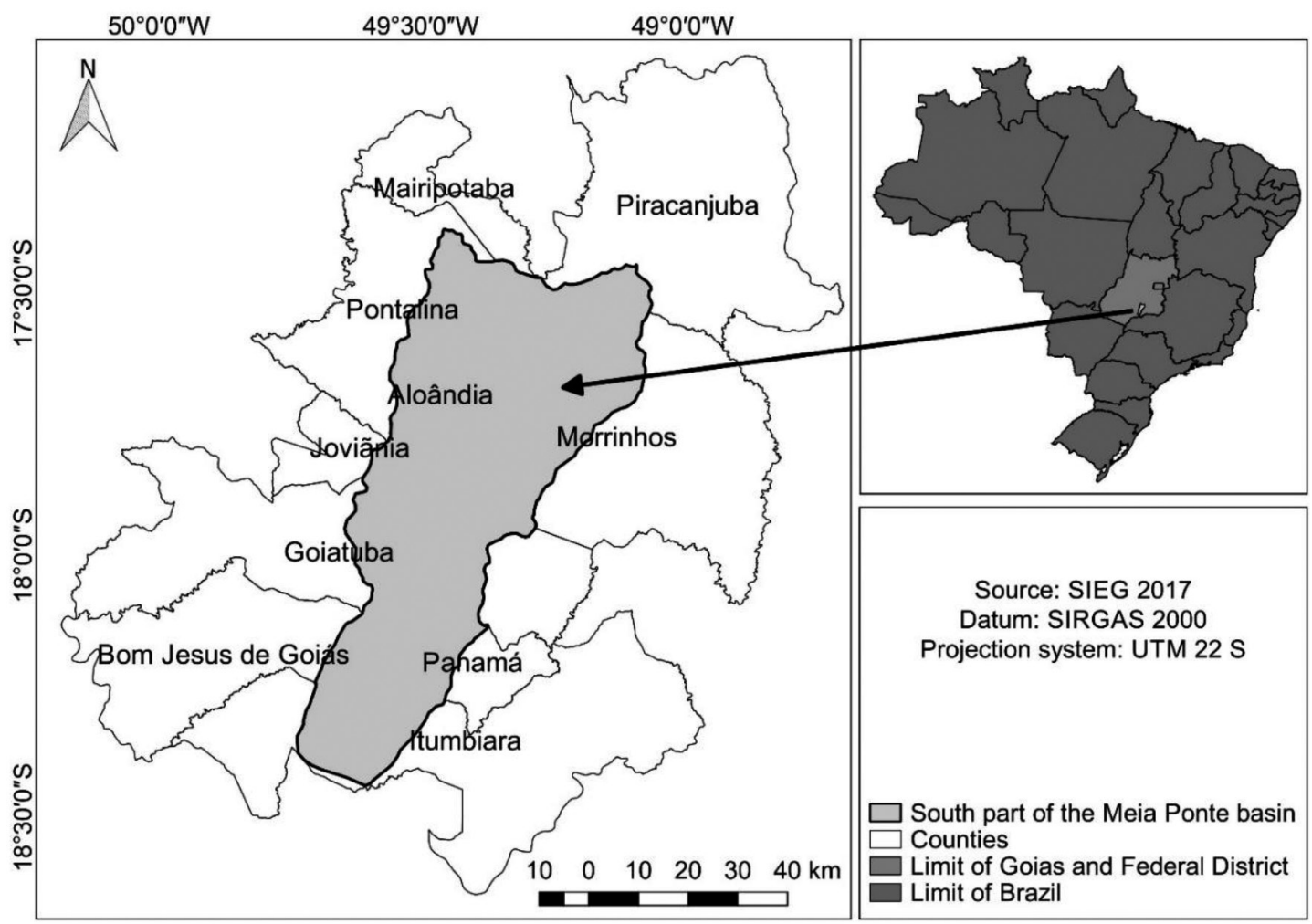

Figure 1. Geographic location of the municipalities and the southern part of the Meia Ponte, Goias hydrographic watershed. 
and occasional drought. The average rainfall is 1346 mm (Alvares et al., 2013). Between October and April, the rainy season, there is an increase in the possibility of new erosion and the expansion of existing erosion because water erosivity tends to be more intense.

For the analysis, we used remote sensing data providing several parameters: lithology, soil class, slope, rain intensity, vegetation index, vicinity of roads and land use, and occupation. The cartographic bases of the lithology and the classes of soils were made available by the State System of Geoinformation (SIEG, 2017). Soil altimetry data were obtained through TOPODATA (INPE, 2017), available in letters (4th to 6th, letter to the millionth), accessed through the National Institute of Space Research. Slope information was generated using the terrain altimetry data.

Precipitation data were obtained from the meteorological station registered under number 1749003 of the National Meteorological Institute, which is under the responsibility of the State University of Goias (Campus Morrinhos), located at latitude $17.72^{\circ} \mathrm{S}$, longitude $49.10^{\circ} \mathrm{W}$, and with an altitude of $814 \mathrm{~m}$. The rainfall intensity mapping was performed using annual precipitation data.

The land cover and Normalized Difference Vegetation Index (NDVI) maps were obtained through images from the Landsat-8 satellite (orbit 222/point 072) with passage on January 10, 2017, obtained from the INPE image catalog (2017). Google Earth images served as an aid for identifying land use and occupation. From the maps generated in the physiographic characterization of the study area, the final map was developed by integrating the lithology, soil class, slope, rain intensity, vegetation index, proximity of roads, and land use data.

All of the information was analyzed in QGIS software (QGIS Development Team, Boston, USA). For the determination of the variables that represent risks from erosion, multicriteria analysis was used through the relationship between the use and occupation of the soil in the southern portion of the Meia Ponte watershed.

For each variable, we established a scale of weights according to erosive susceptibility for natural and anthropogenic environments. For the generation of areas susceptible to erosion, weights and variables proposed by Silva and Machado (2014) were adopted. To generate the final map of susceptibility, the variables were organized in matrix files and weights were assigned to the variables according to the following equations:

\section{a) Natural erosive susceptibility}

$(\mathrm{L} \times 10)+(\mathrm{S} \times 25)+(\mathrm{D} \times 25)+$

$(\mathrm{R} \times 15)+(\mathrm{VI} \times 25)$,

(Equation 1)

where $\mathrm{L}$ is lithology, $\mathrm{S}$ is soil class, $\mathrm{D}$ is declivity, $\mathrm{C}$ is rainfall intensity, and $\mathrm{V}$ is vegetation index.

\section{b) Anthropic erosive susceptibility}

$(\mathrm{L} \times 6)+(\mathrm{S} \times 13)+(\mathrm{D} \times 13)+$

$(\mathrm{R} \times 8)+(\mathrm{V} \times 13)+(\mathrm{PP} \times 12)$

$+(\mathrm{SU} \times 35)$,

(Equation 2)

where $\mathrm{L}$ is lithology, $\mathrm{S}$ is soil class, $\mathrm{D}$ is declivity, $\mathrm{C}$ is rainfall intensity, $\mathrm{V}$ is vegetation index, $\mathrm{PV}$ is proximity of pathways, and SU is soil use.

For the components of each map, grades 1 to 5 were assigned according to characteristics that tend to favor the formation of erosive processes. For the elaboration of the maps with weights, it was necessary to convert the data into vector files and reclassify the images. The variables were adopted using the methodology proposed by Assis et al. (2017) and adapted from Silva and Machado (2014). The final maps were converted into vector files for quantification of area and calculation of the percentage of each class of erosive vulnerability.

\section{Results and Discussion}

The mapping allowed the characterization of the southern part of the Meia Ponte River watershed in relation to geomorphological factors. The analyzed variables allow understanding of the aspects of the region in terms of agricultural fitness and areas susceptible to erosive processes with anthropic or natural action.

The lithological formation of the southern part of the Meia Ponte River watershed presents aspects of having low influence on degradation, considering the areas classified as high and very high (Figure 2A). Because the soil in this area is classified as Latosol, the analyses allowed us to determine that the erosive susceptibility is to a greater extent classified as very low but classified as high or very high in other small portions of the area (Figure 2B). Latosols are more resistant to the 

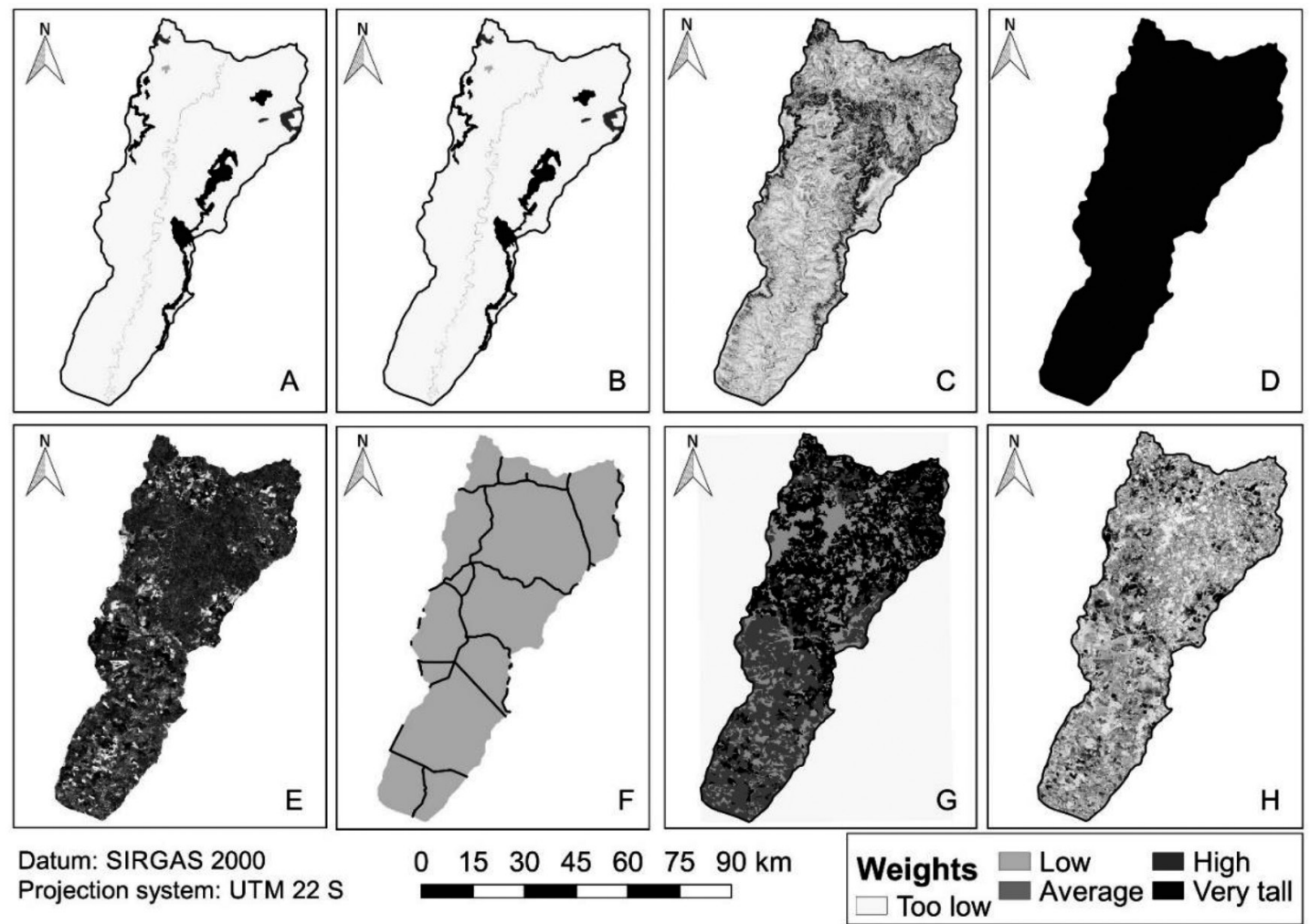

Datum: SIRGAS 2000

Projection system: UTM $22 \mathrm{~S}$
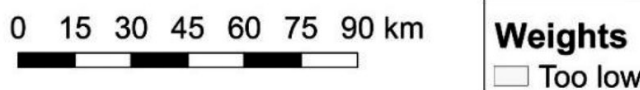

Figure 2. Reclassification of variables for susceptibility to Litology (A), Soil class (B), Declivity (C), Rainfall intensity (D), Vegetation strength (E), Proximity of pathways soil (G), and Landsat image 8, composition R6G5B4 (H).

action of surface runoff due to their good permeability and drainage (Valle Junior et al., 2009).

The declivity of the terrain presents classes of very low, low, medium, and high erosive susceptibility, considering that the slope is classified as low in most of this area (Figure 2C). This can be attributed to the predominance of relief being smoothly curled toward the banks of the streams. Another factor that influences erosion susceptibility as a function of slope is areas located in hills top, with slopes ranging from 10 to $30 \%$ (Saraiva et al., 2016). The shape of the terrain constitutes a qualitative variable, and from its geometry, effects are attributed that can be ordered according to their intensity, while being passive about considering the values of vulnerability to soil loss (Valeriano, 2008; Silva Neto, 2013).

Because the average precipitation in the region varies from 1250 to $1750 \mathrm{~mm}$ per year (Oliveira and Sousa, 2012) with good spatial distribution, low susceptibility to erosive processes was observed, avoiding new erosive processes (Figure 2D).

The NDVI revealed that the vigor of the vegetation was low in most of the area but very low, medium, and high in some regions (Figure 2E). The areas that had high values of NDVI were areas in which the impact caused by the force of drops of precipitation was reduced beneath the soil surface, thus reducing the velocity of water flow and minimizing the removal and transport of aggregates. High values of NDVI also indicate high vigor of vegetation, which minimizes direct contact of precipitation particles with soil and thereby reduces the effects of laminar surface runoff (Guerra, 1998). The absence of vegetation cover makes the soil more vulnerable to inclement weather processes, causing the processes to act more intensely on these areas and thereby weaken them (Guerra, 1999).

In the areas near highways, the influence for susceptibility was classified as high. As the distance from highway increased, erosive susceptibility decreased (Figure 2F). Intense vehicle traffic tends to contribute to intensification of erosion processes. Thus, the opening of highways is a contributing factor of erosive susceptibility (Amaral et al., 2005).

Soil use was the factor that contributed most to erosive susceptibility, especially when there 
was exploitation through agricultural activities. This land use was identified as very low, low, and average (Figure 2G). Variables such as declivity, soil type, and land use should be considered more important variables than terrain forms, because the latter is a qualitative variable in the dynamics of erosive processes (Silva Neto, 2013).

The natural erosive susceptibility was classified as medium or low in the largest portion of the watershed (Figure 3A). However, in the northcentral area of the watershed, the natural erosive susceptibility was classified as high or very high. The map of anthropic erosive susceptibility revealed changes in the natural landscape of the southern part of the Meia Ponte River watershed due to the processes and higher frequency of land use change and occupation by agricultural areas and pastures (Figure 3B).

The main economic activities in these areas were dairy farming and soybean, corn, and sugarcane cropping. All of these activities require intense use of soil, which increases erosive susceptibility. Among these agricultural activities, land use with pasture is considered to be the activity that most contributes to increased risk of erosive susceptibility (Valle Junior et al., 2010).

The areas of natural susceptibility (Figure 4) were concentrated in areas with medium and high susceptibility classes. Anthropogenic susceptibility

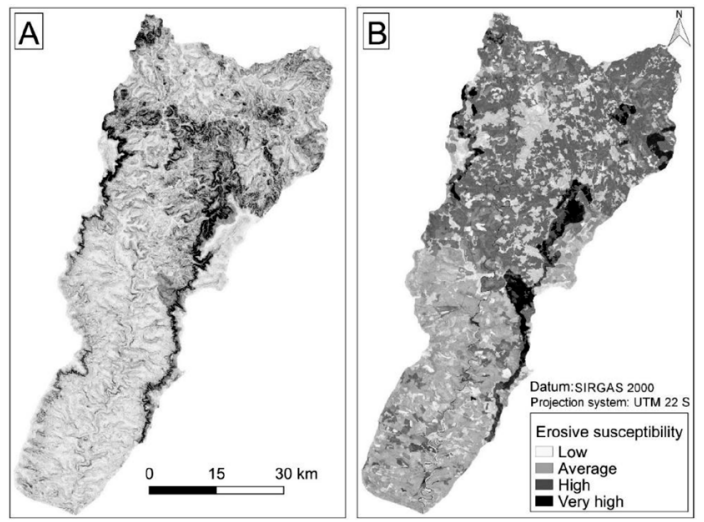

Figure 3. Map of the natural erosive susceptibility (A) and anthropic (B) for the southern part of the Meia Ponte watershed, Goias, 2017.

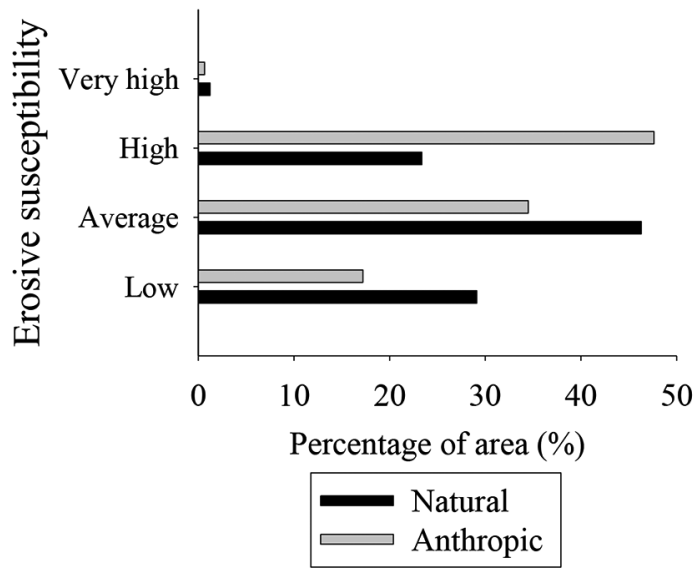

Figure 4. Percentages of areas in the Classes of Natural and Anthropic Erosive Susceptibility of the southern part of the Meia Ponte watershed, Goias, 2017.

was mostly concentrated in medium and low classes. By means of these indicators, it can be affirmed that the anthropic action has greater influence on the erosive susceptibility of the hydrographic watershed of this study.

\section{Conclusions}

The use of multicriteria analysis with GIS tools allowed the combination of qualitative and quantitative variables for erosive susceptibility. In the southern part of the Meia Ponte River watershed, the anthropic factor had greater influence. The factors that increased the susceptibility class in certain areas were soil use and occupation, low vegetation index, and high slope. The southern part of the Meia Ponte River watershed has medium natural erosive susceptibility in most of the study area.

This study and the mapping of the southern part of the Meia Ponte River watershed will serve as a basis for actions aimed at watershed planning, promote discussion of the erosive vulnerability of the region, and assist in management of the region through actions aimed at sustainable development and recovery and the prevention of the emergence of new erosion. 


\section{Literature Cited}

Alvares, C.A.; Stape, J.L.; Sentelhas, P.C; Gonçalves, J.L. de M.; Sparovek, G.

2014. Koppen's climate classification map for Brazil. Meteorologische Zeitschrif, 22: 711-728.

Amaral, E.F. do; Lani, J.L.; Bardales, N.G.; Oliveira, H. de. 2005. Vulnerabilidade ambiental de uma área piloto na Amazonia Ocidental: trecho da BR-364 entre Feijó e Mâncio Lima, Estado do Acre. Natureza e Desenvolvimento, 1(1): 87-102.

Assis, A.P.O.; Giongo, P.R.; Silva, J.H.T.; Pesqueiro, M.A.; Gomes, L.F.

2017. Suscetibilidade erosiva da bacia hidrográfica do Córrego da Formiga, Quirinópolis/GO. Revista Espacios, 38(42): 2-12.

Christofoletti, A.

2011. Aplicabilidade do conhecimento geomorfológico nos projetos de planejamento. In: Guerra, A.J.T.; Cunha, S.B. Geomorfologia: Uma Atualização de Bases e Conceitos. Bertrand Brazil. Rio de Janeiro, Brazil. pp. 415-442.

Guerra, A.J.T.

1998. Processos erosivos nas encostas. In: Guerra, A.J.T.; Cunha, S.B. Geomorfologia: uma atualização de bases e conceitos. Bertrand Brasil. Rio de Janeiro, Brasil. pp. 149-209.

Guerra, A.J.T.

1999. O início do processo erosivo. In: Guerra, A.J.T.;

Silva, A.S.; Botelho, R.G.M. Erosão e conservação dos solos: conceitos, temas e aplicações. Bertrand Brasil. Rio de Janeiro, Brasil. pp. 17-55.

2017. Divisão de Geração de Imagens. Available. ttp:// www.inpe.br/acessoainformacao/dgi_ativ_sem1_2013. Consulted. 1/oct/ 2017.

Ismael, F.C.M., Leite, J.C.A., Gomes, N.A., Medeiros, W. e S., Vale, R.L.

2013. Identificação e avaliação dos impactos ambientais resultantes da erosão do solo na área do Câmpus da UFCG em Pombal - PB. Revista Verde de Agroecologia e Desenvolvimento Sustentável, 8(4): 87-96.

Lepsch, I.F.

2010. Formação e Conservação dos solos. 2th ed. São Paulo: Oficina de Textos.

Moraes, V.H.; Giongo, P.R.; Mesquita, M.; Cavalcante, T.J.;

Ventura, M.V.A.; Costa, E.M.; Arantes, B.H.T.

2019. Analysis of the Impact of Land Use and Occupation on the Biophysical Variables of the Cerrado Biome in
Southwest Goiano, Brazil. Journal of Agricultural Science, 11:(1), 399-409.

Nascimento, M.C.; Soares, V.P.

2005. Uso do Geoprocessamento na Identificação de Conflito de Uso da Terra em Áreas de Preservação Permanente na Bacia Hidrográfica do Rio Alegre, Espírito Santo. Ciência Florestal, 15(2): 207-220.

Oliveira, A.G.; Sousa, A.T.

2012. Especificidades das precipitações pluviométricas na microrregião meia ponte no sul de Goiás e sua relação com a ocorrência de processos erosivos. In: Pesquero, M.A.; Silva, M.V. 2012. Caminhos Interdisciplinares pelo Ambiente, História e Ensino: o Sul Goiano no contexto. 1th ed. Uberlândia: pp. 31-48.

Saraiva, V.I.C.; Silva, A.S.; Santos, J.P.C. dos.

2016. Uso do mapa de solos como subsídio para definição de áreas de suscetibilidade à erosão na bacia hidrográfica São João, Lagos e Una. Geo UERJ, 29: 354-373.

SIEG (Sistema Estadual de Geoinformações).

2016. Download de arquivos SIG. Available: http://www. sieg.go.gov.br Retrived. Consulted: 5/oct/ 2017.

Silva, V.C.; and Machado, P.S.

2014. SIG na análise ambiental: suscetibilidade erosiva da bacia hidrográfica do Córrego Mutuca, Nova Lima - Minas Gerais. Revista de Geografia, 31: 2.

Silva Neto, J.C.A. da.

2013. Avaliação da vulnerabilidade à perda de solos na bacia do rio Salobra, MS, com base nas formas do terreno. Geografia, 22(1): 05-25.

Vale Junior, J.F. do; Barros, L. da S.; Sousa, M.I.L. de; UCHÔA, S.C.P.

2009. Erodibilidade e suscetibilidade à erosão dos solos de cerrado com plantio de Acacia mangium em Roraima. Agroambiente, 3(1): 1-8.

Valeriano, M.M.

2008. Topodata: guia para utilização de dados geomorfológicos locais. São José dos Campos: INPE.

Valle Junior, Renato F. do; Galbiatti, João A.; Martins Filho, Marcílio V.; Pissarra, T.C.T.

2010. Potencial de erosão da bacia do rio Uberaba. Engenharia Agrícola, 30(5): 808-908.

Zanata, J.M., Piroli, E.L.; Delatorre, C.C.M.; Gimenes, G.R. 2012. Análise do uso e ocupação do solo nas áreas de preservação permanente da microbacia Ribeirão Bonito, apoiada em técnicas de geoprocessamento. Revista Geonorte, 2(4): $1262-1272$ 